\title{
In Vitro Effects of 5-Lipoxygenase Pathway Inhibition on Rhinovirus-Associated Bronchial Epithelial Inflammation
}

\author{
Irini Spyridaki $\cdot$ Styliani Taka (1) $\cdot$ Chrysanthi Skevaki • \\ Aikaterini Trochoutsou $\cdot$ Nikolaos G. Papadopoulos
}

Received: December 21, 2020 / Accepted: March 2, 2021 / Published online: April 13, 2021

(C) The Author(s) 2021

\begin{abstract}
Introduction: The leukotriene pathway may be implicated in the induction of virus-induced inflammation. Respiratory epithelial cells may express low levels of 5-lipoxygenase (5-LO) and release leukotrienes (LTs) C4, D4, and E4, upon exposure to viruses or other stimuli. Enhanced expression of 5-LO pathway proteins after
\end{abstract}

Supplementary Information The online version contains supplementary material available at https:// doi.org/10.1007/s41030-021-00152-X.

I. Spyridaki · S. Taka $(\bowtie) \cdot$ C. Skevaki ·

A. Trochoutsou · N. G. Papadopoulos

Allergy Department, 2nd Pediatric Clinic, National and Kapodistrian University of Athens, Athens, Greece

e-mail: staka@med.uoa.gr

\section{Skevaki}

Institute of Laboratory Medicine, Philipps-

Universität Marburg, Marburg, Germany

\section{Skevaki}

Universities of Giessen and Marburg Lung Center (UGMLC), German Center for Lung Research (DZL), Philipps-Universität Marburg, Hannover, Germany

\section{Skevaki}

German Center for Lung Research (DZL), Hannover, Germany

\section{N. G. Papadopoulos}

Division of Infection, Inflammation and Respiratory Medicine, University of Manchester, Manchester, UK rhinovirus (RV) infection has previously been described. We hypothesized that anti-leukotriene treatment of epithelial cells, with or without exposure to RV-infected peripheral blood mononuclear cells (PBMCs)-conditioned media, may inhibit RV-induced up-regulation of inflammatory cytokines.

Methods: PBMCs from a healthy donor were exposed to RV1B and supernatants were harvested at $48 \mathrm{~h}$ post infection. BEAS-2B cells were infected with RV, with or without conditioning with the PBMC supernatant. Treatment with anti-LT agents was performed either on both PBMCs and BEAS-2B or at the bronchial epithelial level only, with varying concentrations of montelukast (CysLT receptor antagonist) or MK-886 [FLAP(5-lipoxygenaseactivating-protein) inhibitor]. Evaluation of the inflammatory cytokines IL-8, RANTES, IL-11, IL6, and IP-10 was performed using ELISA.

Results: Our results show that anti-LT treatment of RV-infected bronchial epithelial cells suppresses epithelial RV-mediated cytokine production, independent of conditioning.

Conclusions: This observation may represent an indirect mode of action of the anti-leukotrienes in virus-induced asthma.

Keywords: Anti-inflammatory; Leukotrienes; Rhinovirus; 5-lipoxygenase 


\section{Key Points}

Bronchial epithelial cell line is shown to produce LTs (LTB4 and cysLTs) following $\mathrm{RV}$ infection.

Anti-LT treated bronchial epithelial cells responded with reduced RV-mediated inflammation.

Inhibition of RV replication is reported after Montelukast (ML) treatment.

5-LO inhibition treatment suppressed the $\mathrm{RV}$-induced inflammation in bronchial epithelial cells.

Inhibition of the 5-LO pathway suppresses the release of RV-induced inflammatory mediators.

\section{DIGITAL FEATURES}

This article is published with digital features, including a summary slide, to facilitate understanding of the article. To view digital features for this article go to https://doi.org/10.6084/ m9.figshare.14134937.

\section{INTRODUCTION}

Viral respiratory infections are the major trigger of asthma exacerbations in adults and children $[25,37]$. Rhinoviruses (RV) belong to the Picornaviridae family of positive single-stranded RNA viruses and are implicated in a variety of respiratory disorders ranging from the common cold to pneumonia, sinusitis, and other respiratory conditions $[13,46,60]$, most prominently to acute asthma exacerbations [25]. Airway inflammation and remodeling are characteristic features of asthma [9] and it is likely that epithelial infection and the subsequent interaction with the epithelial-mesenchymal trophic unit are critical for RV- mediated pathophysiology contributing to asthma exacerbations [20].

Several studies suggest that virus-induced inflammation may also involve the leukotriene (LT) pathway $[5,52]$. There is accumulating evidence that some populations of epithelial cells normally express low levels of 5-lipoxygenase (5-LO) and are thus able to synthesize LTs, despite the fact that LTs are mainly produced by leukocytes [45]. Certain factors, including viral infection, can promote the expression of 5-LO in epithelial cells [34]. Respiratory epithelial cells release LT-C4, D4, and E4, upon exposure to viruses or other stimuli [5].

Montelukast (ML), a potent cysteinyl-leukotriene (CysLT) receptor antagonist, reduces asthma symptoms or cold-induced exacerbations in children and adults [7, 19, 24, 28, 49]. The mechanisms underlying these observations are not fully elucidated, but several explanations have been put forward. RV infection upregulates nuclear factor kappa B (NF-кB) proteins [41], while ML inhibits tumor necrosis factor- $\alpha$ (TNF- $\alpha)$-stimulated interleukin IL-8 expression through changes in NF- $\mathrm{B}$ p65-associated histone acetyltransferase (HAT) activity [57]. Both RV epithelial infection and the leukotriene pathway have been implicated in airway remodeling. RV epithelial infection is able to up-regulate vascular endothelial growth factor (VEGF) and mediate angiogenesis [47], but also stimulate fibroblast proliferation through bFGF (basic fibroblast growth factor) [54]. Leukotriene receptor antagonism was able to reduce remodeling in a mouse model [36].

The lower respiratory epithelium, a principal site of RV infection in relation to asthma exacerbations, produced a variety of mediators augmenting the inflammatory response [40]. Respiratory structural cells produce a broad range of mediators upon viral infection, such as IL-1, IL-6, IL-8, IL-11, eotaxins, RANTES, and IP10 (interferon gamma-induced protein - 10), and most of them are elevated in allergic rhinitis and asthma $[15,16]$.

We hypothesized that RV-induced inflammation is partly mediated through LTs and that LT pathway inhibitors may reduce or prevent such inflammation. Therefore, we examined the effects of ML and MK-886, a 5-LO inhibitor, on 
the inflammatory responses upon RV infection, using two in vitro cell culture systems.

\section{METHODS}

\section{Experimental Design (Supplementary data, Fig. S1)}

\section{Epithelial Leukotriene Release}

In order to study the expression of LTB4 and CysLT mediators following stimulation with several infective doses of RV, BEAS-2B cells were cultured in monolayers on 48-well plates (Corning, Arlington, UK) [63] and exposed to $\mathrm{RV}$ at a multiplicity of infection (MOI) of $0.5,1$, 3 , and 5 or to control medium (Ohio-HeLa cell lysate, $H$ ). Supernatants were removed at 8,24 , 48,72 , and $96 \mathrm{~h}$ after infection, clarified by centrifugation (at $3000 \times g$ for $10 \mathrm{~min}$ at $4{ }^{\circ} \mathrm{C}$ ), and deep-frozen. Cells were stained with crystal violet to assess RV-induced cytotoxicity. LTB4 and CysLT release was evaluated using commercially available enzyme immunoassay kits according to the manufacturer's instructions (Cayman Chemical, MI, USA, lower detectable levels were $13 \mathrm{pg} / \mathrm{ml}$ ).

\section{Inhibition of Leukotriene-Mediated Epithelial Inflammation}

BEAS-2B cells were exposed to $1 \mathrm{MOI}$ of RV or to control medium $(\mathrm{H})$ for $1 \mathrm{~h}$. Virus/control solution was then removed; cells were washed twice and replenished with fresh medium. Several concentrations of ML or MK-886 were added to the cultures after RV infection. ML and the FLAP inhibitor MK-886 were kindly supplied by Merck, USA. Both drugs were diluted as stock in dimethyl sulfoxide (DMSO, Sigma-Aldrich, USA) into $10^{-1} \mathrm{M}$ solutions and after serial dilutions in culture medium, into $10^{-}-10^{-9} \mathrm{M}$. Although ML is typically used as an asthma control drug [29], the drug is often introduced upon the first signs of an asthma exacerbation and in the case of viral-induced episodes, after the exposure to the virus [49]. Therefore, we exposed the cell cultures to leukotriene pathway inhibition after RV infection. The cell cultures were then incubated at $33{ }^{\circ} \mathrm{C}, 5 \% \mathrm{CO}_{2}$. Supernatants were removed at 48 and $72 \mathrm{~h}$ after infection, clarified by centrifugation and deep-frozen. Production of pro-inflammatory and pro-remodeling mediators was evaluated according to the manufacturer's instructions [CCL5 (RANTES), CXCL8 (IL8), IL-11, bFGF, (R\&D Systems, Europe), IL-6 (eBioscience, San Diego, CA, USA)]. RV-induced cytotoxicity was also evaluated by two different methods: using crystal violet staining [63] and measuring lactate dehydrogenase (LDH) release in cell supernatants, according to manufacturer's instructions (TAKARA, Japan).

\section{Inhibition of Epithelial Inflammation in the Context of a Systemic Antiviral Immune Response}

In order to model the effect of leukotriene pathway inhibition on immune-epithelial interactions, we used a previously described model [63]. Supernatants from RV-infected PBMCs were used instead of purified cytokines, to better represent the concentrations of mediators resulting from the in vivo antiviral immune response $[43,63]$. PBMCs were isolated from an adult non-atopic and non-asthmatic donor, as assessed by means of a detailed medical history, skin prick testing, and spirometry. The study was approved by the Medical Ethics Committee of the Panagiotis \& Aglaia Kyriakou Children's Hospital. The donor was informed in detail, both written and verbally, about the process and provided written informed consent. Ethics approval in context of European FP7 programme PREDICTA HEALTH-F22010-260,895 Protocol no 7790/16-05-2011. Briefly, PBMCs were isolated from whole blood by Ficoll centrifugation [39] and exposed to 5 MOI of RV or control medium, with or without ML/MK-886 treatment. Subsequently, BEAS-2B cells were conditioned with the PBMC supernatants and exposed to RV or control. Culture supernatants were then removed and PBMC supernatant as well as several concentrations of ML or MK-886 were added to the fresh culture medium. BEAS-2B cell cultures were then incubated at $33{ }^{\circ} \mathrm{C}, 5 \% \mathrm{CO}_{2}$, and supernatants were harvested at $48-72 \mathrm{~h}$ after exposure to virus or control and inhibition treatment, clarified by centrifugation, and stored at $-80^{\circ} \mathrm{C}$ until further processed. The epithelial inflammatory response was evaluated as described above. 

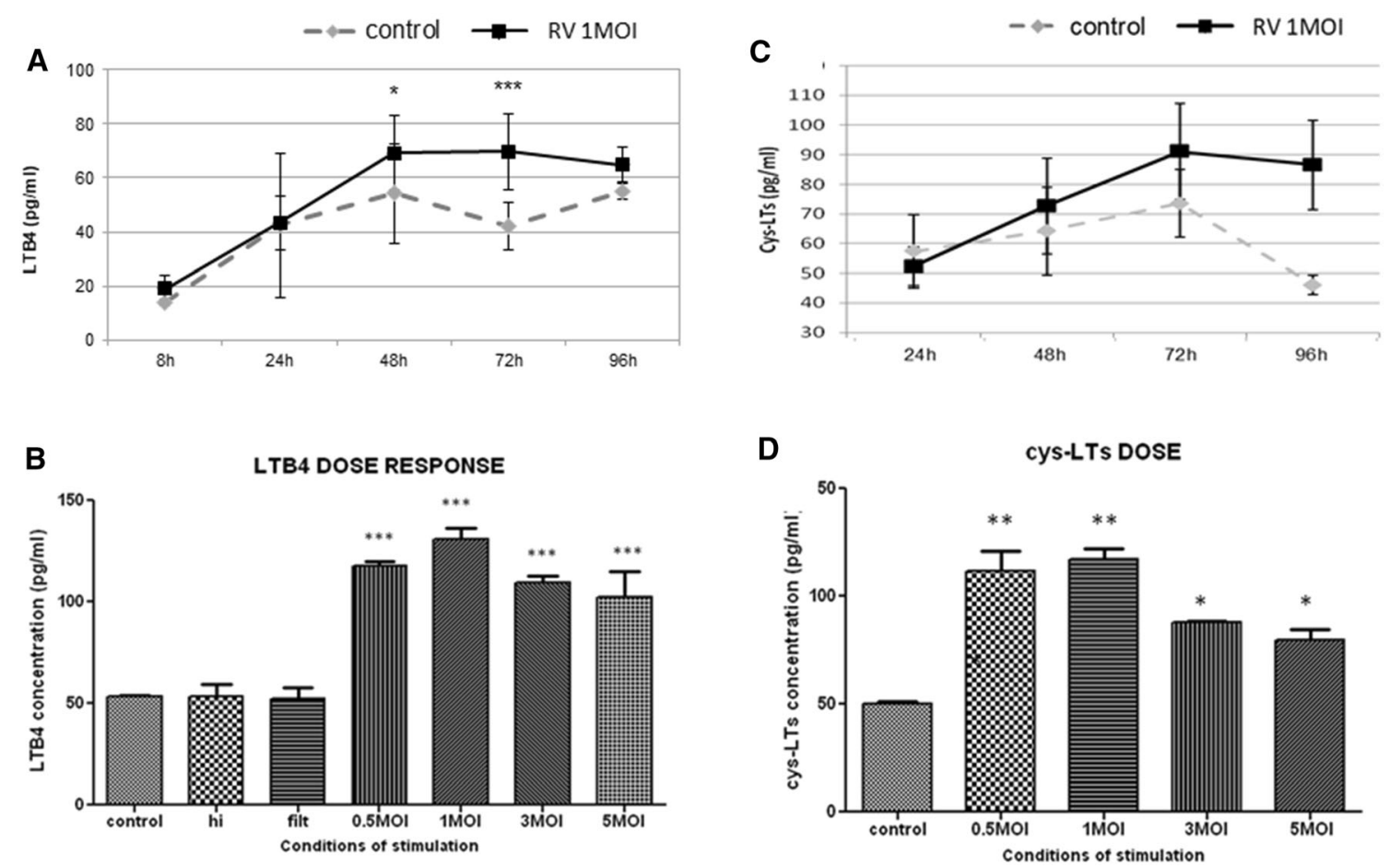

Fig. 1 a Release of LTB4 mediator from BEAS-2B cells at five different time points $(8,24,48,72$, and $96 \mathrm{~h})$ after RV1B infection compared to control $\left({ }^{*} p<0.05\right)$ (a repeated-measures ANOVA was performed). b Release of LTB4 from BEAS-2B cells at $72 \mathrm{~h}$ post-infection with HeLa lysate, heat-inactivated (hi) RV1B, filtered (filt) RV1B and four doses of RV1B $\left(^{* * *} p<0.001\right)$. c Release of

\section{Statistical Analysis}

Distribution normality was assessed using the Kolmogorov-Smirnov test. Data are expressed as means \pm standard errors of the mean and analyzed using a $t$ test for differences between two groups or using one-way ANOVA with Bonferroni's multiple comparison test for subsequent between-group effect evaluation. $p$ values $<0.05$ were considered significant.

\section{RESULTS}

\section{Leukotriene Release (Time and Dose Dependence)}

RV-infected BEAS-2B cells produced significantly higher levels of LTB4, 48 and $72 \mathrm{~h}$ after

CysLTs from BEAS-2B cells at four different time points (24, 48, 72, and $96 \mathrm{~h}$ ) after RV1B infection compared to control $\left({ }^{*} p<0.05\right)$. (a repeated-measures ANOVA was performed). $\mathbf{d}$ Release of CysLTs from BEAS-2B cells at $72 \mathrm{~h}$ post-infection with $\mathrm{HeLa}$ lysate and four doses of $\mathrm{RV} 1 \mathrm{~B}\left({ }^{*} p<0.05,{ }^{* *} p<0.01\right)$

infection compared to control $(p<0.05)$ (Fig. 1a). RV infection at 0.5-5 MOI induced greater release of LTB4 mediators from BEAS$2 \mathrm{~B}$ cells compared to non-infected cells, control and filtered $\mathrm{RV}$ at $t=72 \mathrm{~h} \quad(p<0.001)$ (Fig. 1b). Cell treatment with heat-inactivated or filtered RV did not induce LTB4 release. LTB4 release is higher using 1-MOI RV than using 0.5-MOI, but this response is reduced at higher virus concentrations (3 and 5 MOI) (Fig. 1b). In addition, BEAS-2B cells produced higher levels of CysLTs (LTC4, LTD4, LTE4) at 72 and $96 \mathrm{~h}$ after infection with RV (1 MOI), compared to non-infected cells (Fig. 1c). RV infection at $0.5-5 \mathrm{MOI}$ induced greater release of CysLTs at $96 \mathrm{~h}$ compared to control, with the highest levels observed at 0.5 and 1 MOI $(p<0.01)$ (Fig. 1d). 


\section{Inhibition of Leukotriene-Mediated Epithelial Inflammation}

BEAS-2B cell cultures were next exposed to RV prior to the inhibition of the 5-LO pathway. On the basis of the results of RV-induced LT release, $\mathrm{RV}$ at $1 \mathrm{MOI}$ and at the time points of 48 and $72 \mathrm{~h}$ were chosen for the inhibition experiments. Release of IL-8, IP-10, IL-6, IL-11, and bFGF was evaluated at 48 and $72 \mathrm{~h}$ after infection. Infection with RV induced cytotoxicity at 48 and $72 \mathrm{~h}$ after infection, while treatment with ML or MK-886 did not affect the observed cell death, both among infected and non-infected cells (Fig. S2). RV infection induced significant production of IL-8, IP-10, IL-6, IL-11, and bFGF by BEAS-2B cells exposed to RV, as compared to non-infected cells $(p<0.001)$, while exposure of RV-infected epithelial cells to diluent did not change this effect (data not shown). Treatment with ML significantly inhibited the release of IL-8, IL-6, IP-10, and IL11 from RV-infected BEAS-2B cells after 48 and $72 \mathrm{~h}$, in a dose-dependent manner (Fig. 2a, b, respectively). FGF-2 release was also down-regulated (Fig. 2), but this was significant at higher ML concentrations (Figs. S3 and S4).

\section{Inhibition of Epithelial Inflammation in the Context of a Systemic Antiviral Immune Response}

Subsequently, BEAS-2B cells were stimulated by PBMCs supernatants and infected with RV (conditioned cell cultures). The release of inflammatory cytokines in conditioned cell cultures, treated with $10^{-6} \mathrm{M}$ ML or MK-886 or not, was evaluated at $48 \mathrm{~h}$ post-infection. RV infection induced significant production of IL8, IL-6, RANTES, IP-10, and IL-11 in conditioned cell cultures $(p<0.001)$. Treatment of epithelial cells with RV-infected PBMCs significantly enhanced the virus-induced IL-8, IL-6, RANTES, and IL-11 release. Furthermore, the treatment of conditioned cell cultures with $\mathrm{ML}\left(10^{-6} \mathrm{M}\right)$ and MK-886 $\left(10^{-6} \mathrm{M}\right)$ resulted in significant reduction of cytokine release in supernatants (Fig. 3a). More specifically, the treatment of conditioned cell cultures with ML showed significant reduction of IL-8, IL-6, CCL5, IP-10, and IL-11 $(p<0.001)$ release. Similar results were shown by the treatment of conditioned cells with MK-886 for IL-8 $(p<0.001)$, IL-6 $(p<0.001)$, CCL5 $(p<0.001)$, IP-10 $(p<0.001)$, and IL-11 $(p<0.05)$ release (Fig. 3a). This reduction was sustained in IL-8, CCL5, and IL11 with a lower dose of ML $\left(10^{-9} \mathrm{M}\right)$ and in IL-8 and CCL5 cytokines with a lower dose of MK$866\left(10^{-9} \mathrm{M}\right)$ (Supplement, Fig. 4).

Similarly, exposure of conditioned cell cultures to drug treatment of both cell types induced significant epithelial production of IL8, IL-6, RANTES, IP-10, and IL-11, compared to non-infected cells. On the other hand, exposure of RV-infected epithelial cells to supernatants from RV-infected PBMCs treated with diluent did not enhance this effect (data not shown). Prior treatment of PBMCs with ML at a concentration of $10^{-6} \mathrm{M}$ significantly inhibited the release of IL- 8 and IL-11 by RV-infected BEAS$2 \mathrm{~B}$, while PBMCs treated with MK-886 at concentrations of $10^{-6} \mathrm{M}$ did not show the same result (Fig. 3b). Treatment of PBMCs with ML or MK-886 significantly inhibited the release of IP10, IL-6, and RANTES by RV-infected BEAS-2B (Fig. 3b). This reduction was sustained in IP-10, IL-6, and CCL5 cytokines with higher doses of ML $\left(10^{-4}\right.$ and $\left.10^{-5} \mathrm{M}\right)$ and MK-866 $\left(10^{-4}\right.$ and $10^{-5} \mathrm{M}$ ) (Fig. S5).

In addition to the inhibition of inflammatory responses, significantly lower RV replication was observed in BEAS-2B cells treated with ML and exposed to ML-treated, RV-infected PBMC supernatants at $48 \mathrm{~h}$ post-infection $(p<0.05)$ (Fig. 4).

\section{DISCUSSION}

Structural cells, such as bronchial epithelial cells, have been considered to synthesize leukotrienes by metabolizing LTA4 produced by a leukocyte donor cell because they lack the 5-LO enzyme [45]. However, although LT synthesis was once thought to be restricted to leukocytes, recent studies suggest that some epithelial cell populations express 5-LO at low concentrations and are thus able to synthesize LTs from arachidonate upon stimulation. More 

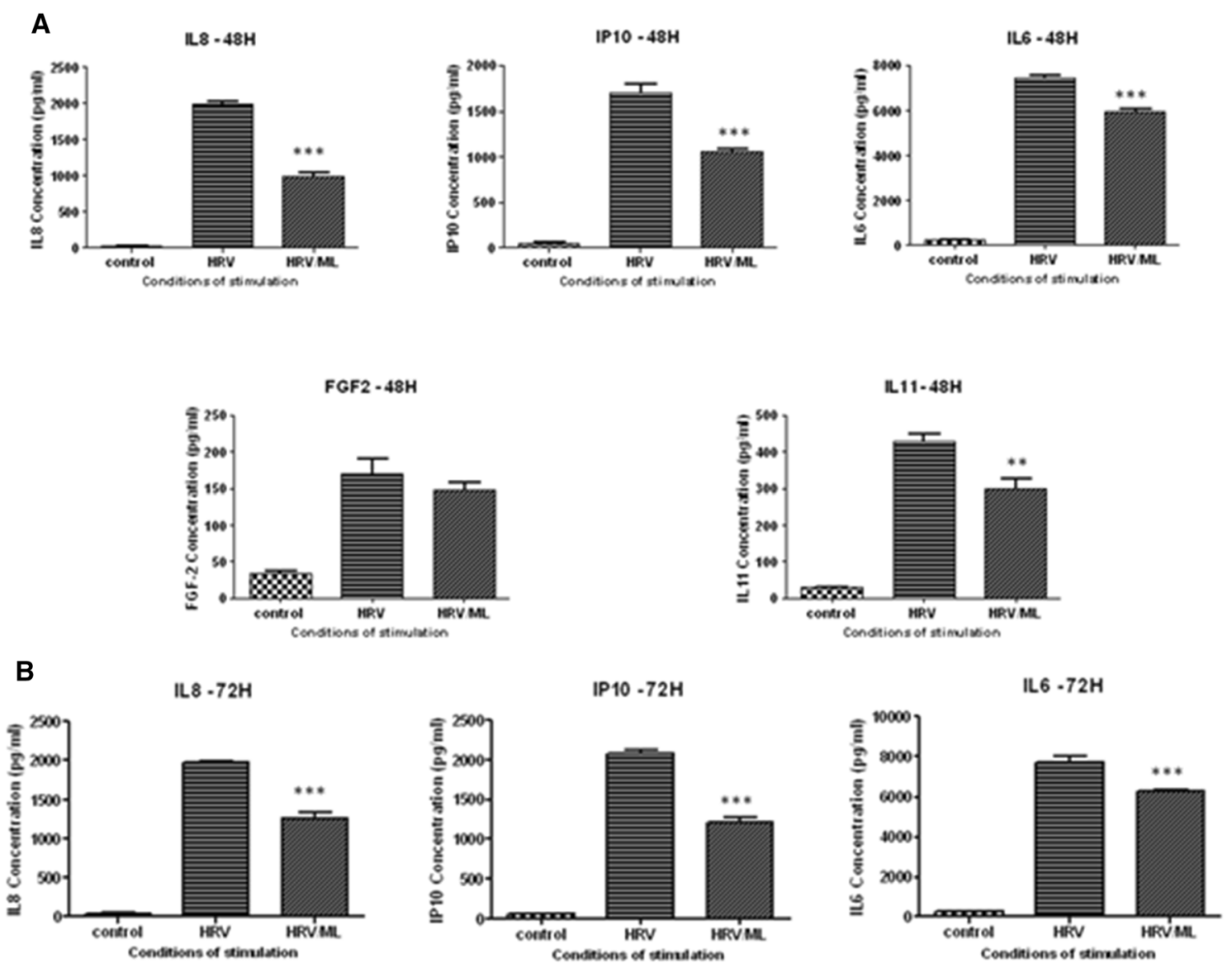

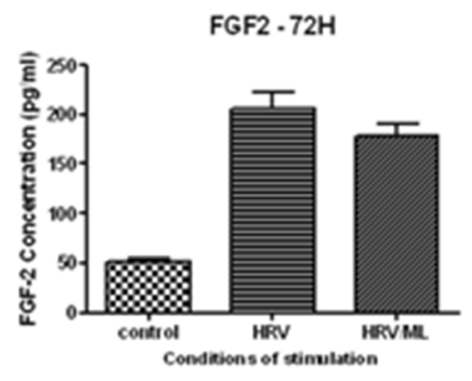

Fig. 2 Cytokine and chemokine production by BEAS-2B cells exposed to RV1B (1 MOI), as compared to noninfected cells after $\mathbf{a} 48 \mathrm{~h}$ and $\mathbf{b} 72 \mathrm{~h}$, with and without the addition of montelukast: IL-8, IP10, IL6, FGF-2, IL11 [B2b-: BEAS-2B cells exposed to HeLa lysate, B2b + :

specifically, it has subsequently been shown that human bronchial epithelial cells [22] and fibroblasts are capable of producing both CysLTs and LTB4 following inflammatory insults [23]. To our knowledge, this is the first

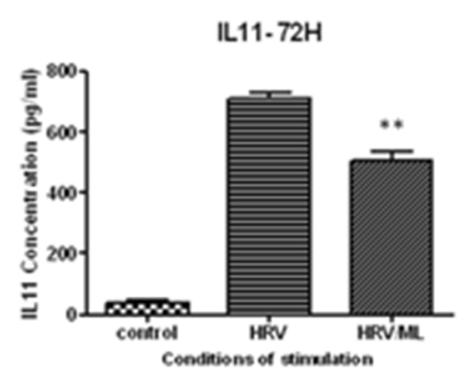

HRV- (human rhinovirus) infected BEAS-2B cells, D: DMSO $1: 10^{6}$, ML: montelukast $\left.10^{-6} \mathrm{M}\right]\left({ }^{* * *} p<0.001\right.$, compared to $\mathrm{B} 2 \mathrm{~b}+$ and $\mathrm{B} 2 \mathrm{~b}+/ \mathrm{D}$ )

time that a bronchial epithelial cell line has been shown to produce LTs (LTB4 and CysLTs) following RV infection. The experiments were performed under serum-free conditions allowing for more precise detection of any differences 
A IL8 (drugs on Beas $2 \mathrm{~b}$ cells)

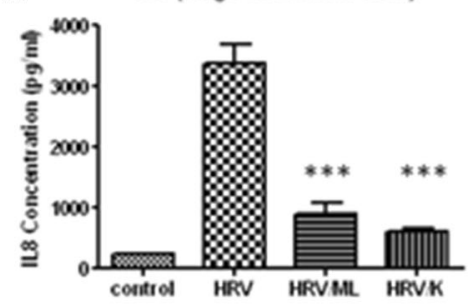

IP 10 (dnugs on Beas $2 b$ cells)

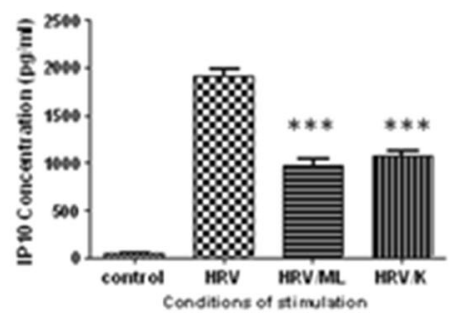

IL6 (dnugs on Beas $2 \mathrm{~b}$ cells)

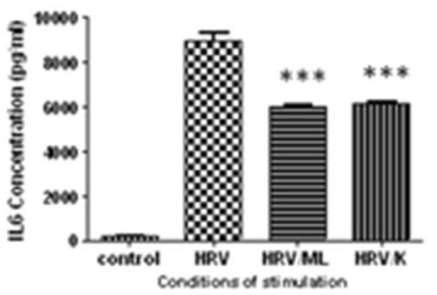

CCL5 (drugs on Beas $2 b$ cells)

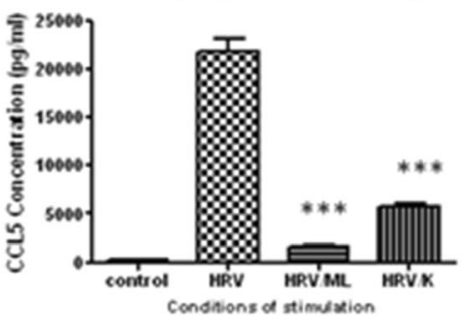

IL11 (drugs on Beas 2b cells)

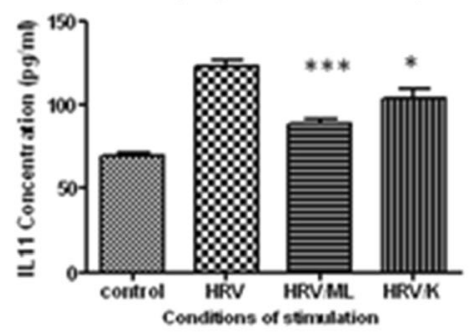

B

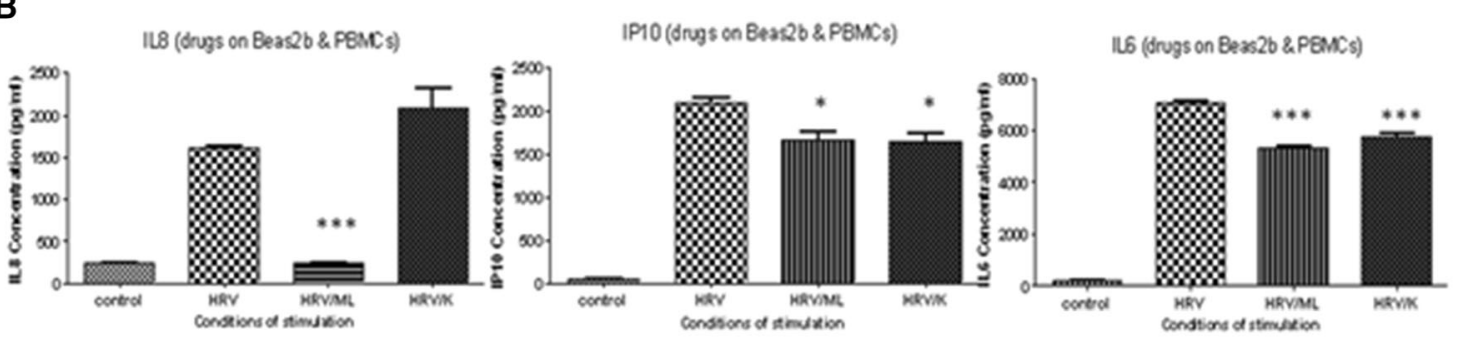

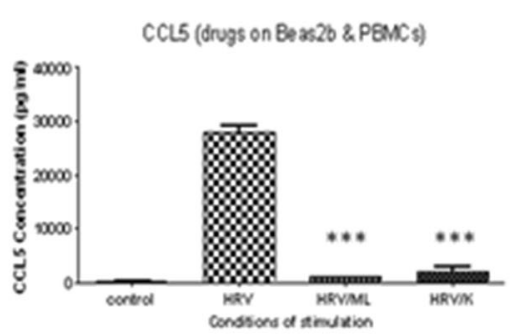

Fig. 3 a Cytokine and chemokine production in supernatants of BEAS-2B cells, in PBMCs and a BEAS-2B cell system, in which only BEAS-2B cells were exposed to RV1B (1 MOI) after $48 \mathrm{~h}$, with and without the addition of montelukast: IL-8, IP10, IL6, CCL5 (RANTES), IL11. b Cytokine and chemokine production in supernatants of BEAS-2B cells, in PBMCs and a BEAS-2B cell system, in which both BEAS-2B cells (1 MOI) and PBMCs (5 MOI)

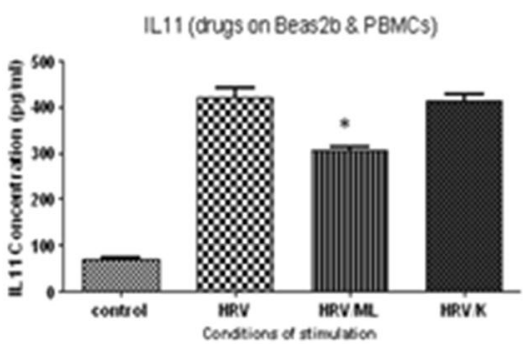

were exposed to RV1B after $48 \mathrm{~h}$, with and without the addition of montelukast [control: BEAS-2B cells exposed to HeLa lysate, HRV/D/HRV: RHRV- (human rhinovirus) infected BEAS-2B cells, d DMSO 1:106, ML: montelukast $10^{-6} \mathrm{M}, \mathrm{K}$ : MK-886 $\left.10^{-6} \mathrm{M}\right]\left({ }^{*} p<0.005\right.$, $\left.{ }^{* *} p<0.01,{ }^{* * *} p<0.001\right)$ 


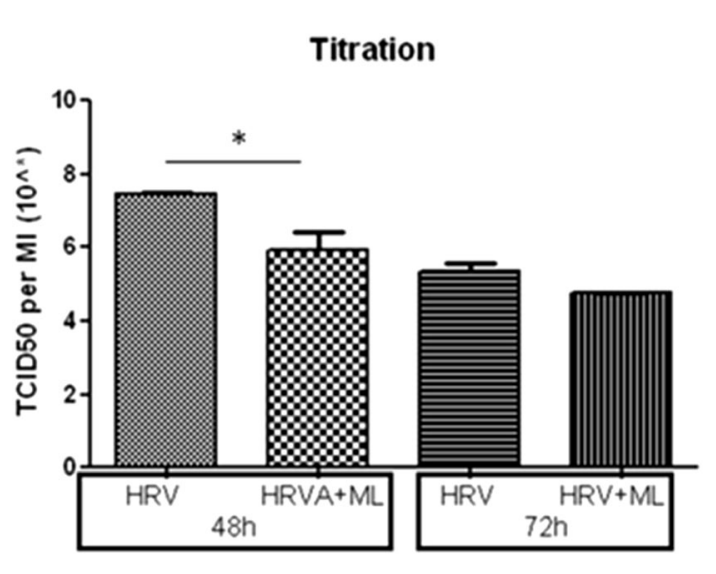

Fig. 4 Titration of RV in supernatants from BEAS-2B cells in PBMCs and a BEAS-2B cell system at 48 and $72 \mathrm{~h}$ post-infection (BEAS-2B-cell infection), with or without ML treatment (M6: Montelukast $\left.10^{-6}\right)\left({ }^{*} p<0.05\right)$ and RV1B

in leukotriene release and better control over physiological responsiveness and evaluation of cellular functions [10, 32].

Bronchial epithelial inflammatory response is a crucial feature of RV infection [53, 62]. In this study, we found significant suppression of the RV-induced inflammation, including the release of IL-8, CCL5, IL-6, IL-11, and IP-10 in bronchial epithelial cells after 5-LO inhibition treatment. Furthermore, we found that anti-LTtreated bronchial epithelial cells exposed to supernatants either of RV-infected PBMCs or anti-LT-treated, RV-infected PBMCs responded with reduced RV-mediated inflammation, which was accompanied by a reduction in virus replication. Interestingly, it is the first time that inhibition of RV replication has been reported after ML treatment, in accordance with clinical studies suggesting improvement of virus-related wheezing with ML $[6,26,66,67]$. Recent studies describe antiviral effects of ML on epithelial cells infected with herpes simplex virus type 1 or adenovirus [21]. Inhibition of the expression of the Influenza A viral genome was observed with ML [18, 27,31]. For the hepatitis $C$ virus, ML induced a dose-dependent decrease in the levels of RNAs expressed, indicating an inhibition of viral replication [51]. ML also attenuated the initial responses to respiratory syncytial virus (RSV) infection in neonate and adult mice $[19,28]$.
However, the relationship between ML and viral infection is not clear. Some data suggest that the antiviral effects of ML may be the result of its anti-inflammatory and anti-allergic properties. The possible relationship between ML and the apoptotic response of the infected cell could also suggest a protective effect of ML against viral infections. Virus-induced genes, such as inflammatory genes, are known to modulate cell death as an antiviral function of the cell [3]. Another study by Andersson et al. [2] showed that montelukast decreased the expression of ICAM-1 (RV1B receptor) in 16HBE cells, which could potentially explain the decrease in viral titer in ML-treated BEAS-2B cells, as well as a reduction in pro-inflammatory cytokines in a more direct manner [2]. Furthermore, not only in in vitro models but also in in vivo studies, ML provides clinical benefit to patients with chronic asthma and decreases bronchial hyperresponsiveness. ML caused a statistically significant decrease of serum concentrations in cytokine, ICAM-1, ECP, and peripheral blood eosinophil counts over the 6-week treatment period. This observation raises the possibility that leukotriene receptor antagonists, such as ML, may have effects on parameters of asthmatic inflammation [56].

More specifically, RV-induced expression of IL-8 is greater than that of other respiratory viruses [12] and is shown to be increased in an atopic environment and associated with enhanced neutrophilic inflammation [11, 17]. On the other hand, ML inhibits IL-8 expression in human leukemic monocyte lymphoma and alveolar basal epithelial cell lines [57, 64]. Furthermore, there seems to be an association between IL-8 and LTs through the TLR4 and NF$\kappa \mathrm{B}$ inflammatory pathway, while inhibition of the CysLT receptor represses TNF- $\alpha$-stimulated IL-8 expression [57]. Besides, 5-LO pathway inhibition may reduce airway inflammation and bronchial hyperresponsiveness, possibly through down-regulation of RV-induced IL-11 and TGF-beta 1 expression [33, 44]. Moreover, ML may inhibit RV-associated inflammatory responses through activities not directly related to antagonism of leukotriene receptors [59], such as inhibition of 5-lipoxygenase [48], histone acetyltransferase (HAT) [57], and 
adenosine $3^{\prime}, 5^{\prime}$-cyclic monophosphate (cAMP) phosphodiesterase [1], as well as interference with purinergic P2Y receptors [48] and inhibition of eosinophil adhesion to vascular endothelium and migration [50]. This may represent an additional, indirect mode of action of anti-leukotriene medication on virus-induced epithelial inflammation.

We found that treatment with ML did not affect the observed cell death, both among infected and non-infected cells, suggesting that ML does not exert their anti-inflammatory action directly through antiviral effects. Although there is a significant reduction of viral replication at $48 \mathrm{~h}$, this was not significant at $72 \mathrm{~h}$ and we found no subsequent effect on the extended in vitro virus-induced epithelial damage.

With the use of a cell-culture system (BEAS$2 \mathrm{~B}$ and PBMCs stimulated), the levels of cytokine elevation were substantially greater than those from one cell type alone, resulting in more lifelike in vitro experiments [30, 42, 47, 54, 63]. Furthermore, another benefit of using this model is the representation of the natural interplay between immune cells, including neutrophils, eosinophils, NK cells, macrophages from blood, and epithelial cells [35]. The intercellular adhesion molecule 1 (ICAM-1) is the major group rhinovirus receptor, a cell-surface glycoprotein that normally regulates leukocyte trafficking and accumulation at sites of inflammation via engagement of lymphocyte function-associated antigen (LFA)1 and macrophage- 1 antigen (Mac-1) on the cell surface [55]. This may be a potential mechanism by which a virus spreads in the airways and results in the mutual interaction between asthma and rhinitis, for which there is considerable clinical evidence [14, 38].

The main limitation of this study is the use of a bronchial cell line instead of primary bronchial epithelial cells. The difficulty of collecting bronchial cells from donors was the main reason for this experimental drawback. Another limitation of this study was the lack of in vivo experiments, but such investigations are beyond the scope of this paper, as the fact that ML effectively inhibits the inflammatory activities of the 5-LO pathway has already been described and is part of numerous international guidelines for asthma therapy [4, 8]. Another possible disadvantage of our study design is that the level of viremia following a rhinovirus infection is low [61]. However, the percentage of rhinoviremia is higher in asthmatics, suggesting that the direct exposure of the PBMCs significantly contributes to the asthmatic inflammatory response to RV infections.

Our findings support our initial hypothesis that bronchial epithelial cells produce significant amounts of leukotrienes, while inhibition of the 5-LO pathway suppresses the release of $\mathrm{RV}$-induced inflammatory mediators.

\section{CONCLUSIONS}

In summary, the results of this study support the concept that bronchial epithelial cells are able to synthesize leukotrienes and this production is induced by RV infection. Montelukast and a FLAP inhibitor (MK-866) suppressed RV-induced inflammatory responses. This is the first time that inhibition of rhinovirus replication after montelukast treatment has been reported. These findings identify an important role for CysLT in RV-induced airway responses and provide novel insights into prophylactic approaches for the prevention of RVmediated sequelae in patients with asthma.

\section{ACKNOWLEDGEMENTS}

Funding. Supported in part by a research grant from the Investigator-Initiated Studies Program of Merck. The opinions expressed in this paper are those of the authors and do not necessarily represent those of Merck. Supported by Universities of Giessen and Marburg Lung Center (UGMLC), the German Center for Lung Research (DZL), the Rhön Klinikum, and the Deutsche Forschungsgemeinschaft (DFG)-funded SFB 1021 (C04), KFO 309 (P10), and GZ: SK 317/1-1, AOBJ: 661487 (Skevaki C.). No funding or sponsorship was received for this study or publication of this article. 
Authorship. All named authors meet the International Committee of Medical Journal Editors (ICMJE) criteria for authorship for this article, take responsibility for the integrity of the work as a whole, and have given their approval for this version to be published. Irini Spyridaki, supported in part by a research grant from the Investigator-Initiated Studies Program of Merck, performed the experimental procedure. Aikaterini Trochoutsou performed cell cultures and ELISA. Chrysanthi Skevaki designed the study. Styliani Taka and Irini Spyridaki wrote the manuscript. Nikolaos G. Papadopoulos supervised the project.

Disclosures. Styliani Taka, Aikaterini Trochoutsou has nothing to disclose. Irini Spyridaki was supported in part by a research grant from the Investigator-Initiated Studies Program of Merck. Chrysanthi Skevaki has received research funding by Hycor Biomedical, Bencard Allergie and Thermo Fisher Scientific; Research Funding, Mead Johnson Nutrition (MJN). Nikolaos G. Papadopoulos has received Research Support from Gerolymatos International SA and Capricare and is in advisory board of HAL, Menarini/Faes Farma, Novartis, Nutricia, GSK, AstraZeneca, Mylan/Meda.

Compliance with Ethics Guidelines. The study was approved by the Medical Ethics Committee of the Panagiotis \& Aglaia Kyriakou Children's Hospital. The donor was informed in detail, both written and verbally, about the process and provided written informed consent. Ethics approval in context of European FP7 programme PREDICTA HEALTH-F22010-260,895 Protocol no 7790/16-05-2011.

Data Availability. All data generated or analyzed during this study are included in this published article/as supplementary information files.

Open Access. This article is licensed under a Creative Commons Attribution-NonCommercial 4.0 International License, which permits any non-commercial use, sharing, adaptation, distribution and reproduction in any medium or format, as long as you give appropriate credit to the original author(s) and the source, provide a link to the Creative Commons licence, and indicate if changes were made. The images or other third party material in this article are included in the article's Creative Commons licence, unless indicated otherwise in a credit line to the material. If material is not included in the article's Creative Commons licence and your intended use is not permitted by statutory regulation or exceeds the permitted use, you will need to obtain permission directly from the copyright holder. To view a copy of this licence, visit http://creativecommons.org/licenses/by$\mathrm{nc} / 4.0 /$.

\section{REFERENCES}

1. Anderson R, Theron AJ, Gravett CM, Steel HC, Tintinger GR, Feldman C. Montelukast inhibits neutrophil pro-inflammatory activity by a cyclic AMP-dependent mechanism. Br J Pharmacol. 2009;156:105-15.

2. Andersson K, Shebani EB, Makeeva N, Roomans GM, Servetnyk Z. Corticosteroids and montelukast: effects on airway epithelial and human umbilical vein endothelial cells. Lung. 2010;188:209-16.

3. Barber GN. Cytoplasmic DNA innate immune pathways. Immunol Rev. 2011;243:99-108.

4. Bateman ED, Hurd SS, Barnes PJ, Bousquet J, Drazen JM, FitzGerald M, Gibson P, Ohta K, O'Byrne P, Pedersen SE, Pizzichini E, Sullivan SD, Wenzel SE, Zar HJ. Global strategy for asthma management and prevention: GINA executive summary. Eur Respir J. 2008;31:143-78.

5. Behera AK, Kumar M, Matsuse H, Lockey RF, Mohapatra SS. Respiratory syncytial virus induces the expression of 5-lipoxygenase and endothelin-1 in bronchial epithelial cells. Biochem Biophys Res Commun. 1998;251:704-9.

6. Bisgaard H. A randomized trial of montelukast in respiratory syncytial virus postbronchiolitis. Am J Respir Crit Care Med. 2003;167:379-83.

7. Bisgaard H, Zielen S, Garcia-Garcia ML, Johnston SL, Gilles L, Menten J, Tozzi CA, Polos P. Montelukast reduces asthma exacerbations in 2- to 5 -year-old children with intermittent asthma. Am J Respir Crit Care Med. 2005;171:315-22. 
8. Boulet LP, Reddel HK, Bateman E, Pedersen S, FitzGerald JM, O'Byrne PM. The Global Initiative for Asthma (GINA): 25 years later. Eur Respir J. 2019. PMID: 31273040 Review.

9. Bousquet J, Jeffery PK, Busse WW, Johnson M, Vignola AM. 'Asthma. From bronchoconstriction to airways inflammation and remodeling. Am J Respir Crit Care Med. 2000;161:1720-45.

10. Brunner D, Frank J, Appl H, Schoffl H, Pfaller W, Gstraunthaler G. Serum-free cell culture: the serumfree media interactive online database. Altex. 2010;27:53-62.

11. Cakebread JA, Haitchi HM, Xu Y, Holgate ST, Roberts G, Davies DE. Rhinovirus-16 induced release of IP-10 and IL-8 is augmented by Th2 cytokines in a pediatric bronchial epithelial cell model. PLoS ONE. 2014;9:e94010.

12. Chun YH, Park JY, Lee H, Kim HS, Won S, Joe HJ, Chung WJ, Yoon JS, Kim HH, Kim JT, Lee JS. Rhinovirus-infected epithelial cells produce more IL-8 and RANTES compared with other respiratory viruses. Allergy Asthma Immunol Res. 2013;5: 216-23.

13. Corne JM, Marshall C, Smith S, Schreiber J, Sanderson G, Holgate ST, Johnston SL. Frequency, severity, and duration of rhinovirus infections in asthmatic and non-asthmatic individuals: a longitudinal cohort study. Lancet. 2002;359:831-4.

14. Domachowske JB, Rosenberg HF. Respiratory syncytial virus infection: immune response, immunopathogenesis, and treatment. Clin Microbiol Rev. 1999;12:298-309.

15. Gelfand EW. Inflammatory mediators in allergic rhinitis. J Allergy Clin Immunol. 2004;114:S135-8.

16. Gern JE, French DA, Grindle KA, Brockman-Schneider RA, Konno S, Busse WW. Double-stranded RNA induces the synthesis of specific chemokines by bronchial epithelial cells. Am J Respir Cell Mol Biol. 2003;28:731-7.

17. Gern JE, Vrtis R, Grindle KA, Swenson C, Busse WW. Relationship of upper and lower airway cytokines to outcome of experimental rhinovirus infection. Am J Respir Crit Care Med. 2000;162: 2226-31.

18. Hamilton AL, Watson RM, Wyile G, O'Byrne PM. Attenuation of early and late phase allergen-induced bronchoconstriction in asthmatic subjects by a 5-lipoxygenase activating protein antagonist, BAYx 1005. Thorax. 1997;52:348-54.

19. Han J, Jia Y, Takeda K, Shiraishi Y, Okamoto M, Dakhama A, Gelfand EW. Montelukast during primary infection prevents airway hyperresponsiveness and inflammation after reinfection with respiratory syncytial virus. Am J Respir Crit Care Med. 2010;182:455-63.

20. Holgate ST, Davies DE, Lackie PM, Wilson SJ, Puddicombe SM, Lordan JL. Epithelial-mesenchymal interactions in the pathogenesis of asthma. J Allergy Clin Immunol. 2000;105:193-204.

21. Igde M, Yazici Z. Possible antiviral activity of montelukast against Herpes Simplex Virus type-1 and Human Adeno Virus in vitro. Afr J Microbiol Res. 2012;6:197-202.

22. Jame AJ, Lackie PM, Cazaly AM, Sayers I, Penrose JF, Holgate ST, Sampson AP. Human bronchial epithelial cells express an active and inducible biosynthetic pathway for leukotrienes B4 and C4. Clin Exp Allergy. 2007;37:880-92.

23. James AJ, Penrose JF, Cazaly AM, Holgate ST, Sampson AP. Human bronchial fibroblasts express the 5-lipoxygenase pathway. Respir Res. 2006;7: 102.

24. Johnston NW, Mandhane PJ, Dai J, Duncan JM, Greene JM, Lambert K, Sears MR. Attenuation of the September epidemic of asthma exacerbations in children: a randomized, controlled trial of montelukast added to usual therapy. Pediatrics. 2007;120:e702-12.

25. Johnston SL, Pattemore PK, Sanderson G, Smith S, Lampe F, Josephs L, Symington P, O'Toole S, Myint SH, Tyrrell DA, Holgate ST. Community study of role of viral infections in exacerbations of asthma in 9-11 year old children. BMJ. 1995;310:1225-9.

26. Kelly JT, Busse WW. Host immune responses to rhinovirus: mechanisms in asthma. J Allergy Clin Immunol. 2008;122:671-82 (quiz 83-4).

27. Kent SE, Boyce M, Diamant Z, Singh D, O'Connor BJ, Saggu PS, Norris V. The 5-lipoxygenase-activating protein inhibitor, GSK2190915, attenuates the early and late responses to inhaled allergen in mild asthma. Clin Exp Allergy. 2013;43:177-86.

28. Kloepfer KM, DeMore JP, Vrtis RF, Swenson CA, Gaworski KL, Bork JA, Evans MD, Gern JE. Effects of montelukast on patients with asthma after experimental inoculation with human rhinovirus 16. Ann Allergy Asthma Immunol. 2011;106:252-7.

29. Knorr B, Franchi LM, Bisgaard H, Vermeulen JH, LeSouef P, Santanello N, Michele TM, Reiss TF, Nguyen HH, Bratton DL. Montelukast, a leukotriene receptor antagonist, for the treatment of persistent asthma in children aged 2 to 5 years. Pediatrics. 2001;108:E48. 
30. Korpi-Steiner NL, Valkenaar SM, Bates ME, Evans MD, Gern JE, Bertics PJ. Human monocytic cells direct the robust release of CXCL10 by bronchial epithelial cells during rhinovirus infection. Clin Exp Allergy. 2010;40:1203-13.

31. Landeras-Bueno S, Fernández Y, Falcón A, Oliveros JC, Ortín J. 'Chemical genomics identifies the PERK-mediated unfolded protein stress response as a cellular target for influenza virus inhibition. mBio. 2016;7(2):e00085-e116.

32. Lechner JF, Haugen A, McClendon IA, Pettis EW. Clonal growth of normal adult human bronchial epithelial cells in a serum-free medium. Vitro. 1982;18:633-42.

33. Lee KS, Kim SR, Park HS, Park SJ, Min KH, Lee KY, Jin SM, Lee YC. Cysteinyl leukotriene upregulates IL-11 expression in allergic airway disease of mice. J Allergy Clin Immunol. 2007;119:141-9.

34. Luo M, Lee $S$, Brock TG. Leukotriene synthesis by epithelial cells. Histol Histopathol. 2003;18:587-95.

35. Message SD, Johnston SL. Host defense function of the airway epithelium in health and disease: clinical background. J Leukoc Biol. 2004;75:5-17.

36. Muz MH, Deveci F, Bulut Y, Ilhan N, Yekeler H, Turgut $\mathrm{T}$. The effects of low dose leukotriene receptor antagonist therapy on airway remodeling and cysteinyl leukotriene expression in a mouse asthma model. Exp Mol Med. 2006;38:109-18.

37. Nicholson KG, Kent J, Ireland DC. Respiratory viruses and exacerbations of asthma in adults. BMJ. 1993;307:982-6.

38. Papadopoulos NG, Sanderson G, Hunter J, Johnston SL. Rhinoviruses replicate effectively at lower airway temperatures. J Med Virol. 1999;58:100-4.

39. Papadopoulos NG, Stanciu LA, Papi A, Holgate ST, Johnston SL. A defective type 1 response to rhinovirus in atopic asthma. Thorax. 2002;57:328-32.

40. Papadopoulos NG, Xepapadaki P, Mallia P, Brusselle G, Watelet JB, Xatzipsalti M, Foteinos G, van Drunen CM, Fokkens WJ, D'Ambrosio C, Bonini S, Bossios A, Lotvall J, van Cauwenberge P, Holgate ST, Canonica GW, Szczeklik A, Rohde G, Kimpen J, Pitkaranta A, Makela M, Chanez P, Ring J, Johnston SL. Mechanisms of virus-induced asthma exacerbations: state-of-the-art. A GA2LEN and InterAirways document. Allergy. 2007;62:457-70.

41. Papi A, Johnston SL. Rhinovirus infection induces expression of its own receptor intercellular adhesion molecule 1 (ICAM-1) via increased NF-kappaBmediated transcription. J Biol Chem. 1999;274: 9707-20.
42. Parker LC, Prestwich EC, Ward JR, Smythe E, Berry A, Triantafilou M, Triantafilou K, Sabroe I. A phosphatidylserine species inhibits a range of TLR- but not IL-1beta-induced inflammatory responses by disruption of membrane microdomains. J Immunol. 2008;181:5606-17.

43. Parry DE, Busse WW, Sukow KA, Dick CR, Swenson C, Gern JE. Rhinovirus-induced PBMC responses and outcome of experimental infection in allergic subjects. J Allergy Clin Immunol. 2000;105:692-8.

44. Perng DW, Wu YC, Chang KT, Wu MT, Chiou YC, Su KC, Perng RP, Lee YC. Leukotriene C4 induces TGF-beta1 production in airway epithelium via p38 kinase pathway. Am J Respir Cell Mol Biol. 2006;34: $101-7$.

45. Peters-Golden M, Henderson WR Jr. Leukotrienes. N Engl J Med. 2007;357:1841-54.

46. Pitkaranta A, Arruda E, Malmberg H, Hayden FG. Detection of rhinovirus in sinus brushings of patients with acute community-acquired sinusitis by reverse transcription-PCR. J Clin Microbiol. 1997;35:1791-3.

47. Psarras S, Volonaki E, Skevaki CL, Xatzipsalti M, Bossios A, Pratsinis H, Tsigkos S, Gourgiotis D, Constantopoulos AG, Papapetropoulos A, SaxoniPapageorgiou P, Papadopoulos NG. Vascular endothelial growth factor-mediated induction of angiogenesis by human rhinoviruses. J Allergy Clin Immunol. 2006;117:291-7.

48. Ramires R, Caiaffa MF, Tursi A, Haeggstrom JZ, Macchia L. Novel inhibitory effect on 5-lipoxygenase activity by the anti-asthma drug montelukast. Biochem Biophys Res Commun. 2004;324:815-21.

49. Robertson CF, Price D, Henry R, Mellis C, Glasgow N, Fitzgerald D, Lee AJ, Turner J, Sant M. Shortcourse montelukast for intermittent asthma in children: a randomized controlled trial. Am J Respir Crit Care Med. 2007;175:323-9.

50. Robinson AJ, Kashanin D, O'Dowd F, Williams V, Walsh GM. Montelukast inhibition of resting and GM-CSF-stimulated eosinophil adhesion to VCAM1 under flow conditions appears independent of cysLT(1)R antagonism. J Leukoc Biol. 2008;83: 1522-9.

51. Ruiz I, Nevers Q, Hernández E, Ahnou N, Brillet R, Softic L, Donati F, Berry F, Hamadat S, Fourati S, Pawlotsky JM, Ahmed-Belkacem A. MK-571, a cysteinyl leukotriene receptor 1 antagonist, inhibits hepatitis $\mathrm{C}$ virus replication. Antimicrob Agents Chemother. 2020;64(6):e02078-e2119.

52. Seymour ML, Gilby N, Bardin PG, Fraenkel DJ, Sanderson G, Penrose JF, Holgate ST, Johnston SL, 
Sampson AP. Rhinovirus infection increases 5 -lipoxygenase and cyclooxygenase- 2 in bronchial biopsy specimens from nonatopic subjects. J Infect Dis. $2002 ; 185: 540-4$.

53. Skevaki CL, Christodoulou I, Spyridaki IS, Tiniakou I, Georgiou V, Xepapadaki P, Kafetzis DA, Papadopoulos NG. Budesonide and formoterol inhibit inflammatory mediator production by bronchial epithelial cells infected with rhinovirus. Clin Exp Allergy. 2009;39:1700-10.

54. Skevaki CL, Psarras S, Volonaki E, Pratsinis H, Spyridaki IS, Gaga M, Georgiou V, Vittorakis S, Telcian AG, Maggina P, Kletsas D, Gourgiotis D, Johnston SL, Papadopoulos NG. Rhinovirus-induced basic fibroblast growth factor release mediates airway remodeling features. Clin Transl Allergy. 2012;2:14.

55. Smith CW, Marlin SD, Rothlein R, Toman C, Anderson DC. Cooperative interactions of LFA-1 and Mac-1 with intercellular adhesion molecule-1 in facilitating adherence and transendothelial migration of human neutrophils in vitro. J Clin Invest. 1989;83:2008-17.

56. Stelmach I, Jerzynska J, Kuna P. A randomized, double-blind trial of the effect of treatment with montelukast on bronchial hyperresponsiveness and serum eosinophilic cationic protein (ECP), soluble interleukin 2 receptor (sIL-2R), IL-4, and soluble intercellular adhesion molecule 1 (sICAM-1) in children with asthma. J Allergy Clin Immunol. 2002;109:257-63.

57. Tahan F, Jazrawi E, Moodley T, Rovati GE, Adcock IM. Montelukast inhibits tumour necrosis factoralpha-mediated interleukin- 8 expression through inhibition of nuclear factor-kappaB p65-associated histone acetyltransferase activity. Clin Exp Allergy. 2008;38:805-11.

58. Thompson C, Cloutier A, Bosse Y, Thivierge M, Gouill CL, Larivee P, McDonald PP, Stankova J, Rola-Pleszczynski M. CysLT1 receptor engagement induces activator protein-1- and NF-kappaB-dependent IL-8 expression. Am J Respir Cell Mol Biol. 2006;35:697-704.
59. Tintinger GR, Feldman C, Theron AJ, Anderson R. Montelukast: more than a cysteinyl leukotriene receptor antagonist? Sci World J. 2010;10:2403-13.

60. Tsolia MN, Psarras S, Bossios A, Audi H, Paldanius M, Gourgiotis D, Kallergi K, Kafetzis DA, Constantopoulos A, Papadopoulos NG. Etiology of community-acquired pneumonia in hospitalized school-age children: evidence for high prevalence of viral infections. Clin Infect Dis. 2004;39:681-6.

61. Xatzipsalti M, Kyrana S, Tsolia M, Psarras S, Bossios A, Laza-Stanca V, Johnston SL, Papadopoulos NG. Rhinovirus viremia in children with respiratory infections. Am J Respir Crit Care Med. 2005;172: 1037-40.

62. Xatzipsalti M, Papadopoulos NG. Cellular and animals models for rhinovirus infection in asthma. Contrib Microbiol. 2007;14:33-41.

63. Xatzipsalti M, Psarros F, Konstantinou G, Gaga M, Gourgiotis D, Saxoni-Papageorgiou P, Papadopoulos NG. Modulation of the epithelial inflammatory response to rhinovirus in an atopic environment. Clin Exp Allergy. 2008;38:466-72.

64. Yang YF, Hsu JY, Fu LS, Weng YS, Chu JJ. Asthma drugs counter-regulate interleukin-8 release stimulated by sodium sulfite in an A549 cell line. J Asthma. 2009;46:238-43.

65. Yoshisue H, Kirkham-Brown J, Healy E, Holgate ST, Sampson AP, Davies DE. Cysteinyl leukotrienes synergize with growth factors to induce proliferation of human bronchial fibroblasts. J Allergy Clin Immunol. 2007;119:132-40.

66. Zedan M, Gamil N, El-Assmy M, Fayez E, Nasef N, Fouda A, Settin A. Montelukast as an episodic modifier for acute viral bronchiolitis: a randomized trial. Allergy Asthma Proc. 2010;31:147-53.

67. Zou YX, Zhang J, Ma C, Li J, Zai J, Guo YS. Clinical efficacy of montelukast sodium in treating infantile wheezing. Eur Rev Med Pharmacol Sci. 2014;18: 775-80. 